\title{
Phylogeny and evolutionary history of queen polymorphic Myrmecina ants (Hymenoptera: Formicidae)
}

\author{
Florian M. STEINER ${ }^{1,2, *}$, Birgit C. SCHLICK-STEINER ${ }^{1,2, *, * *}$, HeINo KONRAD $^{1}$, Timothy A. LINKSVAYER $^{3}$, \\ Swee-Peck QUEK ${ }^{4}$, ERHARd CHRISTIAN $^{2}$, Christian STAUFFER $^{1}$ and Alfred BUSCHINGER ${ }^{5}$ \\ ${ }^{1}$ Institute of Forest Entomology, Forest Pathology and Forest Protection, Department of Forest and Soil Sciences; ${ }^{2}$ Institute of \\ Zoology, Department of Integrative Biology and Biodiversity Research, Boku, University of Natural Resources \& Applied Life \\ Sciences, Vienna, Gregor-Mendel-Str. 33, A-1180 Vienna, Austria; e-mail: brigit.florian@gmail.com \\ ${ }^{3}$ Department of Biology, Indiana University, Bloomington, IN 47405, USA \\ ${ }^{4}$ Museum of Comparative Zoology, 26 Oxford Street, Cambridge, MA 02138, USA \\ ${ }^{5}$ Rossbergring 18, D-64354 Reinheim, Germany
}

Key words. Formicidae, Myrmecina, intermorphic queens, queen polymorphism, mitochondrial DNA, cytochrome oxidase I, phylogeny, evolutionary history, historical biogeography

\begin{abstract}
The phylogenetic relationships in the myrmicine ant genus Myrmecina were analyzed using 1,281 bp of the mitochondrial cytochrome c oxidase I gene. Intermorphic queens observed in M. graminicola (Europe), M. nipponica (Japan), M. americana (North America; reported for the first time) and M. sp. A (Java) were reconstructed as an ancestral trait in this genus. Molecularclock-based age estimates suggest that queen polymorphism evolved in Myrmecina at the latest during the Miocene. In terms of biogeographical regions, the inferred chronological order of divergence is: (oriental, (nearctic, (western palearctic, eastern palearctic))).
\end{abstract}

\section{INTRODUCTION}

Myrmecina ants are rarely encountered as they are tiny and live in the soil, leaf litter and rotten logs, and colonies typically consist of less than 100 individuals (Ward, 2005). The genus is widespread in the nearctic, palearctic, oriental and austral regions (Bolton, 1995), with about 30 described (Agosti \& Johnson, 2005) and several recognised but formally undescribed species (e.g., Ito \& Aoki, 2003; Quek et al., 2004). Three morphologically very similar taxa, the western palearctic Myrmecina graminicola (Latreille, 1802), the eastern palearctic M. nipponica Wheeler, 1906 and the nearctic M. americana Emery, 1895, are the subject of taxonomic dispute: the latter two were considered to be subspecies of M. graminicola, but are currently regarded as separate species for morphological reasons (see Bolton, 1995 for details; Onoyama, 1997).

Myrmecina ants display a sociobiological feature termed "queen polymorphism", which is the occurrence within a species of two different phenotypes of reproductive females. Intermorphic queens are wingless and more or less workerlike. Gynomorphic queens are larger, dealate and have enlarged thoraces (Fig. 1). Such queen polymorphism was discovered fairly recently in Myrmecina (Ohkawara et al., 1993). In Japanese populations of $M$. nipponica single colonies contain mostly one or the other queen morph and only occasionally both of them (Ohkawara et al., 1993; Murakami et al., 2000, 2002), whereas in German M. graminicola populations the two queen types frequently co-occur in one nest: gynomorphs may have intermorphic offspring and vice versa, hence both types may be encountered temporarily within a colony during the reproductive season (Buschinger \& Schreiber, 2002; Buschinger, 2005). In the rare M. sp. A from Java only intermorphic queens have been found ("ergatoid queens": Ito, 1996). Intermorphic queens are reported here for the first time in the North American $M$. americana. As a consequence of the cryptic life-style of Myrmecina ants and the relatively recent discovery of queen dimorphism in the genus, little is known about the geographical distribution of the two queen morphs, but at least in M. graminicola queen polymorphism appears to be widespread (Buschinger et al., 2003), possibly over the entire species range.

The origin and maintenance of polyphenism and alternative social strategies are hotly debated topics in ant biology. Some authors have suggested a role for epigenetic regulation (reviewed by Miura, 2005) while others have shown the importance of genetic determination or a combination of genetic and environmental components (Fraser et al., 2000; Rüppell et al., 2001; Krieger \& Ross, 2002; Volny \& Gordon, 2002; Hughes et al., 2003; Bargum et al., 2004; Linksvayer, 2005). Breeding experiments, using queen polymorphic ants including Myrmecina graminicola, have demonstrated a genetic component (Winter \& Buschinger, 1986; Heinze \& Buschinger, 1989; Buschinger, 2005) underlying these traits.

In this paper a phylogeny of Myrmecina species with intermorphic queens is presented. In particular, the

\footnotetext{
* These authors contributed equally to the work.

** Corresponding author.
} 
TABLE 1. Samples of Myrmecina americana, M. graminicola, M. nipponica, M. sp. A from Java and M. sp. from Sabah. Localities: $\mathrm{AU}=$ Austria, FR $=$ France, $\mathrm{GM}=$ Germany, $\mathrm{HU}=$ Hungary, JA = Japan, ID = Indonesia, MY = Malaysia, US = United States of America; $\mathrm{IN}=$ Indiana, $\mathrm{MN}=$ Minnesota, $\mathrm{NC}=$ North Carolina, $\mathrm{OH}=$ Ohio. Collectors (leg.): $\mathrm{AB}=\mathrm{A} . \mathrm{Buschinger}, \mathrm{AT}=$ A. Tartally, B\&F = B.C. Schlick-Steiner \& F.M. Steiner, KO=K. Ohkawara, SM = S. Miyazaki, SQ = S.-P. Quek, TL = T. Linksvayer. Samples $C O I$ sequenced indicated by haplotype (HT) numbers, which correspond to those in Fig. 1. Sample code numbers (in the collections of $\mathrm{AB}$ and $\mathrm{B} \& \mathrm{~F}$ ) are given.

\begin{tabular}{|c|c|c|c|c|}
\hline Species & Locality & leg. & HT & code \\
\hline \multirow{10}{*}{$\begin{array}{c}\text { M. americana } \\
\text { Emery, } 1895\end{array}$} & US: IN, Griffy Nature Reserve & $\mathrm{TL}$ & 6 & AB 16.172; B\&F 14.190 \\
\hline & US: IN, Griffy Nature Reserve & $\mathrm{TL}$ & 6 & AB 16.173; B\&F 14.191 \\
\hline & US: IN, Griffy Nature Reserve & $\mathrm{TL}$ & & AB 16.174 \\
\hline & US: IN, Griffy Nature Reserve & $\mathrm{TL}$ & 6 & AB 16.175; B\&F 14.192 \\
\hline & US: IN, Griffy Nature Reserve & $\mathrm{TL}$ & & AB 16.176 \\
\hline & US: MN, Rochester & $\mathrm{TL}$ & 1 & B\&F 14.640 \\
\hline & US: NC, Cherokee & $\mathrm{TL}$ & 5 & $\mathrm{~B} \& \mathrm{~F} 14.641$ \\
\hline & US: NC, Cherokee & $\mathrm{TL}$ & 4 & $\mathrm{~B} \& \mathrm{~F} 14.642$ \\
\hline & US: OH, Pundersen State Park & $\mathrm{AB}$ & 2 & AB 16.191; B\&F 14.763 \\
\hline & US: OH, Pundersen State Park & US: OH, Pundersen State Park & 3 & AB 16.192; B\&F 14.764 \\
\hline \multirow{8}{*}{$\begin{array}{l}\text { M. graminicola } \\
\text { (Latreille, 1802) }\end{array}$} & AU: Pfaffenmaiß & $\mathrm{B} \& \mathrm{~F}$ & 7 & $\mathrm{~B} \& \mathrm{~F} 12.774$ \\
\hline & AU: Saager vic. Gallizien & $\mathrm{AB}$ & 9 & $\mathrm{~B} \& \mathrm{~F}$ 14.912; AB16.125 \\
\hline & AU: Saager vic. Gallizien & $\mathrm{AB}$ & 7 & $\mathrm{~B} \& \mathrm{~F}$ 14.913; AB16.127 \\
\hline & FR: Besançon & $\mathrm{AB}$ & 10 & B\&F 14.908; AB 16.143 \\
\hline & GM: Gambach & $\mathrm{AB}$ & 8 & $\mathrm{~B} \& \mathrm{~F} 14.914 ; \mathrm{AB} 15.952$ \\
\hline & GM: Klingenberg & $\mathrm{AB}$ & 7 & $\mathrm{~B} \& \mathrm{~F} 14.910 ; \mathrm{AB} 15.986$ \\
\hline & GM: Wertheim & $\mathrm{AB}$ & 7 & B\&F 14.909; AB 15.963 \\
\hline & HU: Bükk mountains & AT & 7 & $\mathrm{~B} \& \mathrm{~F}$ 14.218; AB 16.183 \\
\hline \multirow{3}{*}{$\begin{array}{l}\text { M. nipponica } \\
\text { Wheeler, } 1906\end{array}$} & JA: Kanazawa & $\mathrm{KO}$ & 11 & B\&F 14.209 \\
\hline & JA: Kanazawa & $\mathrm{KO}$ & 11 & B\&F 14.210 \\
\hline & JA: Tomakomai & SM & 12 & B\&F 14.226 \\
\hline M. sp. A (Java) & ID: Java, Bogor & $\mathrm{KO}$ & 13 & B\&F 15.176 \\
\hline M. sp. (Sabah) & MY: Sabah, Crocker Range & SQ & 14 & \\
\hline
\end{tabular}

validity of a recent morphologically based taxonomy of M. americana, M. graminicola and M. nipponica is examined, queen polymorphism is mapped onto the phylogeny to determine whether queen polymorphism is an ancestral or a derived trait in this genus, the phylogenetic tree is used to estimate the age of queen polymorphism in $\mathrm{Myr}$ mecina and the phylogenetic divergence of major lineages in terms of historical biogeography is discussed.

\section{MATERIALS AND METHODS}

\section{Samples}

Twenty three colonies of Myrmecina spp. from eight regions worldwide (Table 1), including all species known to have intermorphic queens, were studied: 10 colonies of $M$. americana (widely distributed in the USA and southern Canada: Creighton, 1950; Brown, 1967; Francoeur, 2000; checklists at http://www.antdata.org/), 8 of $M$. graminicola (widespread in the western palearctic region: Czechowski et al., 2002), 3 of $M$. nipponica (known from Japan and Korea: Ogata \& Terayama, 2003), 1 of $M$. sp. A (currently only known from the Botanical Garden in Bogor, Java) and, in addition, one colony of a species for which the queens are unknown, $M$. sp. from Sabah. Voucher specimens are deposited in the private collections of A. Buschinger, B.C. Schlick-Steiner and F.M. Steiner. Three of the $M$. graminicola colonies were analyzed by Buschinger et al. (2003) in their investigation of the geographic distribution of queen morphs in M. graminicola: $\mathrm{B} \& \mathrm{~F} 12.774, \mathrm{~B} \& \mathrm{~F} 14.912=\mathrm{AB}$ 16.125 and $\mathrm{B} \& \mathrm{~F} 14.913=\mathrm{AB} 16.127$ (Table 1$)$.

\section{Identification of functional queens in M. americana}

M. americana colonies were collected as completely as possible and screened for female sexuals. Intermorphs were identified using characters established for $M$. graminicola (Buschinger \& Schreiber, 2002), mainly thorax shape and eye size. Gynomorphs and intermorphs were dissected to determine their reproductive status (Buschinger \& Alloway, 1978; Alloway et al., 1982): inseminated and egg-laying, inseminated but not egg-laying, and virgin. Ovarioles were counted. Three colonies of $M$. americana $(\mathrm{AB} 16.172=\mathrm{B} \& \mathrm{~F} 14.190, \mathrm{AB}$ $16.173=\mathrm{B} \& \mathrm{~F}$ 14.191, AB 16.175 = B\&F 14.192) were kept in the laboratory as described by Buschinger \& Schreiber (2002) and any female sexual offspring was classified as gynomorph or intermorph.

\section{Molecular analyses}

The genetic analyses included 21 colonies (Table 1): $8 \mathrm{M}$. americana, 8 M. graminicola, 3 M. nipponica, 1 M. sp. A (Java) and $1 M$. sp. (Sabah). DNA extractions and PCR reactions using a touchdown program followed the standard procedures of Schlick-Steiner et al. (2005). The primers used for amplification of the approximately 1,500 bp long cytochrome c oxidase subunit I (COI) mitochondrial gene segment were "LCO1490" (Folmer et al., 1994) and "Pat" (Simon et al., 1994). PCR products were purified using the QIAquick PCR purification kit 
(Qiagen, Hilden, Germany), subsequently sequenced in both directions using the Big Dye termination reaction chemistry (Applied Biosystems, Foster City, CA, USA) and analyzed using an ABI 377 automatic sequencer (Applied Biosystems).

Nucleotide sequences were aligned with default settings of Clustal X (Thompson et al., 1997). 1,281 bp of COI were used in the phylogenetic analyses under distance (Neighbour-Joining algorithm, NJ) and maximum parsimony (MP) criteria using PAUP* (test version 4.0b3a; Swofford, 1998). Bayesian inference using Markov Chain Monte Carlo sampling (BMCMC) was done in MrBayes 3.1 (Ronquist \& Huelsenbeck, 2003). Tamura-Nei distances were used for the NJ tree. In addition to unweighted MP analysis, successive weighting was performed using the rescaled consistency index with heuristic search (TBR algorithm and random taxon addition). Support for both the NJ and MP trees was assessed with 1,000 bootstrap replicates. Prior to BMCMC analysis the GTR $+\mathrm{I}+\mathrm{G}$ model (Tavaré, 1986; Yang, 1993) was selected by Modeltest 3.06 (Posada \& Crandall, 1998), using hierarchical likelihood ratio tests (LRT; Huelsenbeck \& Rannala, 1997), which determines the concordance of data with competing substitution models. In the BMCMC analysis $1,000,000$ generations with a sampling frequency of 100 were run twice. After 200,000 generations stationarity was achieved (average standard deviation of split frequencies constantly staying below 0.005 , until the end of the run) and the last 8,000 trees of each run was used to compute a majority rule consensus tree assigning posterior probabilities of tree topology. Homologous sequences of the following Myrmicinae were used as an outgroup in all the phylogenetic analyses: Messor cf. structor (Latreille, 1798) (DQ074333), Aphaenogaster iberica Emery, 1908 (DQ074361), Myrmica rubra (Linnaeus, 1758) (DQ074378) and Manica rubida (Latreille, 1802) (AY280592).

To test for constancy of evolutionary rates among the ingroup taxa, LRT implemented in PAUP* under the GTR $+\mathrm{I}+\mathrm{G}$ model was used, with and without a molecular clock enforced. Because LRT found no significant deviations from rate constancy at a significance level of 0.05 , the global rate minimum deformation (GRMD) method was applied in TREEFINDER version June 2005 (Jobb et al., 2004) to infer a chronogram from the BMCMC tree. GRMD is applicable for near-clocklike phylograms when the assumption of a global rate is reasonable (Jobb, 2005). Minimum edge length was set to 0.0001. Due to a lack of fossil records the age estimates were based on an assumed molecular clock for COI. Two mutation rates were taken from the literature: the conventional arthropod mtDNA rate of $2.3 \%$ per million years (Brower, 1994) and $1.5 \%$ per million years for $C O I$ as assessed across several arthropod groups (Quek et al., 2004). Well-supported nodes within the divergence range of 1.5 and $10.0 \%$ (as proposed by Quek et al., 2004) were used as fixation points for inferring the age of other branches.

\section{RESULTS}

The newly-discovered intermorphs in $M$. americana were similar to workers in their external morphology except for their larger eyes. The intermorphs resembled "I1" and "I2" in Fig. 1 of Buschinger \& Schreiber (2002) and Figs. 5e and 5f in Miyazaki et al. (2005). In three of the ten analyzed $M$. americana colonies no female reproductives were observed. In six colonies (from Indiana, North Carolina and Ohio) a total of 12 intermorphic gynes was found. Three intermorphs from three colonies died during transport $(\mathrm{AB} 16.173=\mathrm{B} \& \mathrm{~F}$ 14.191, $\mathrm{AB}$ 16.176, B\&F 14.641). Dissection of the remaining intermorphs showed that two (from different colonies:
TABLE 2. Ovariole numbers recorded for $M$. americana, $M$. graminicola, M. nipponica and M. sp. A, in the present study and the literature.

\begin{tabular}{ccc}
\hline Species & Ovariole number & Source \\
\hline M. americana & mean $=9.0(\mathrm{n}=8)$ & present study \\
M. graminicola & mean $=12.1(\mathrm{n}=67)$ & Buschinger \& \\
& Schreiber (2002) \\
M. nipponica & mean $=9.0(\mathrm{n}=207)$ & Murakami et al. (2002) \\
M. sp. A (Java) & $1-9$ (no details given) & Ito (1996) \\
\hline
\end{tabular}

$\mathrm{AB}$ 16.174, $\mathrm{AB} 16.192=\mathrm{B} \& \mathrm{~F}$ 14.764) were inseminated and egg-laying, hence functional queens. The remaining seven individuals were either inseminated but not egglaying, or virgin and partly co-existing with functional intermorphic queens in the same colony (AB 16.192= $\mathrm{B} \& \mathrm{~F}$ 14.764: 1 intermorphic queen, 2 mated but not egglaying intermorphs, 2 virgin intermorphs). The mean number of ovarioles per intermorph was $9.0(\mathrm{n}=8$, Table 2). A single colony of $M$. americana (from North Carolina: B\&F 14.642) contained one gynomorph, which was detected only after ethanol preservation and therefore not dissected. One of the colonies that contained intermorphs in the field (AB 16.173 $=\mathrm{B} \& \mathrm{~F} 14.191)$ and two further colonies $(\mathrm{AB} 16.172=\mathrm{B} \& \mathrm{~F}$ 14.190, $\mathrm{AB} 16.175=\mathrm{B} \& \mathrm{~F}$ 14.192) produced intermorphic gynes in the laboratory, the latter by rearing brood collected in the field.

Sequences of the mitochondrial COI gene $(1,281 \mathrm{bp})$ of the Myrmecina samples analyzed are deposited in GenBank under accession numbers AY443792 and DQ249321-DQ249340. No indels were found in the alignment. Within this COI stretch, 383 sites were variable and 240 parsimony-informative. 75 variable sites were on the first codon position, 18 on the second, and 290 on the third. In our sample, intraspecific COI variation within species ranged from $0.2 \%$ in M. graminicola to $6.2 \%$ in $M$. nipponica, and interspecific sequence divergence within the genus Myrmecina varied from $8.3 \%$ between $M$. nipponica and M. graminicola to $17.3 \%$ between $M$. sp. A and $M$. sp from Sabah.

Phylogenetic trees based on distance, MP and BMCMC analyses were topologically identical, and all Myrmecina clades were very well supported (Fig. 1). To account for a possible saturation effect on the phylogenetic signal at the third codon position, all phylogenetic analyses were additionally conducted using only the first and second positions of COI (tree not shown). This did not change the topology. To calibrate the time line for the chronogram, the age of two calibration points, Cal 1 and Cal 2 (Fig. 1), were estimated by calculating the mean divergence between the descendent sister taxa: $8.37 \% \pm 0.65 \mathrm{SE}$ for Cal $1 ; 3.49 \% \pm 0.43 \mathrm{SE}$ for Cal 2. Both of these were used as calibration points, as well as the two combined. This procedure, and the use of different mutation rates, gave a broad range of age estimates. The oldest node was estimated as 21.9-10.2 Ma (mega-annum), the most recent node of interest as 7.7-3.7 Ma (Fig. 2). 


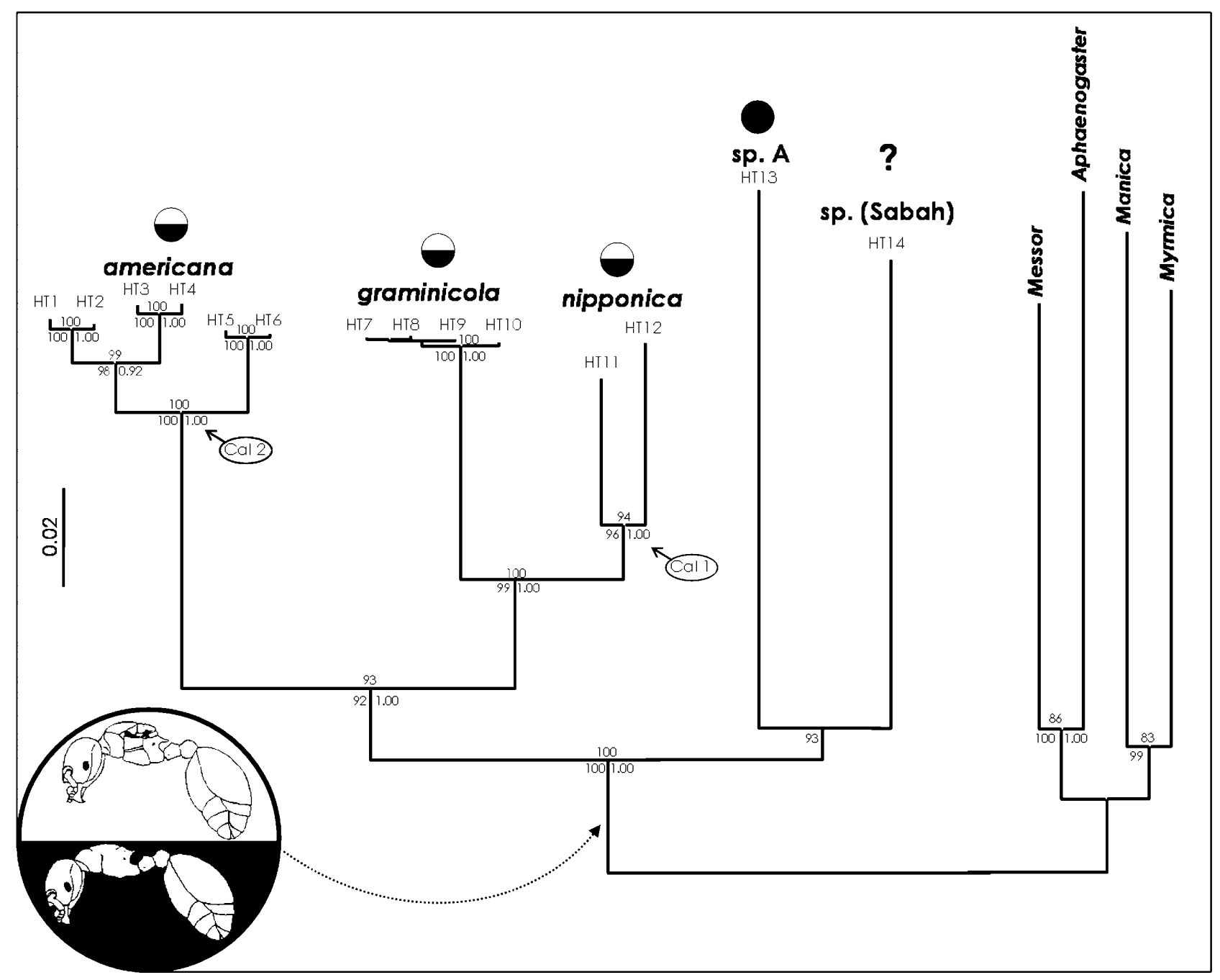

Fig. 1. Phylogeny of queen polymorphism in the ant genus Myrmecina. Neighbour Joining tree of the 14 haplotypes (HT, Table 1) from Myrmecina americana, M. graminicola, M. nipponica, M. sp. A, and M. sp. (Sabah), with Messor cf. structor, Aphaenogaster iberica, Manica rubida and Myrmica rubra as outgroups, calculated with Tamura-Nei distances using 1,281 bp of the COI gene. The scale bar denotes 0.02 substitutions / site. Bootstrap values $>75 \%$ are given above nodes, bootstrap values of the congruent MP branches by successive weighting are to the left of nodes, posterior probability values $>0.75$ of the congruent BMCMC branches to the right of nodes. Queen morphs in Myrmecina are indicated by circles: gynomorphic queens white, intermorphic queens black; queens of $M$. sp. (Sabah) were not collected. Inferred evolutionary origin of queen polymorphism is indicated. Cal 1, Cal $2=$ calibration points for age estimates.

\section{DISCUSSION}

\section{Intermorphic queens in M. americana}

This study demonstrates that intermorphs are functional queens in the North American $M$. americana. This finding adds another continent to the distribution map of intermorphic queens in Myrmecina. Intermorphs appear widespread in North America. As dealate gynomorphs were also repeatedly collected (e.g., Emery, 1895; Creighton, 1950; present data), M. americana is probably queen polymorphic. Due to the small sample size, the occurrence of functional polygyny (the presence of more than one functional intermorphic queen in a colony, as frequently found in $M$. graminicola, Buschinger \& Schreiber, 2002, and M. sp. A, Ito, 1996) remains questionable in $M$. americana. It is likewise premature to deduce that functional monogyny (the presence of mated but non-laying gynes in a colony together with the functional egg-laying queen; as suggested for $M$. nipponica, Ohkawara et al., 1993; Murakami et al., 2000) occurs in $M$. americana, from the fact that mated intermorphs were once found along with one egg-laying intermorphic queen. As for ovariole numbers in intermorphs (Table 2), $M$. americana lies close to $M$. nipponica (Murakami et al., 2002) and halfway between $M$. sp. A (Ito, 1996) and M. graminicola (Buschinger \& Schreiber, 2002).

\section{Systematic implications}

The mitochondrial gene phylogeny supports the current morphology-based taxonomic classification of $M$. nipponica, M. graminicola and M. americana. Separation at the species level is confirmed by divergence values of $C O I$ (Fig. 1), which parallel or even exceed those of the same gene stretch in Cardiocondyla, Cataglyphis, Formica, 


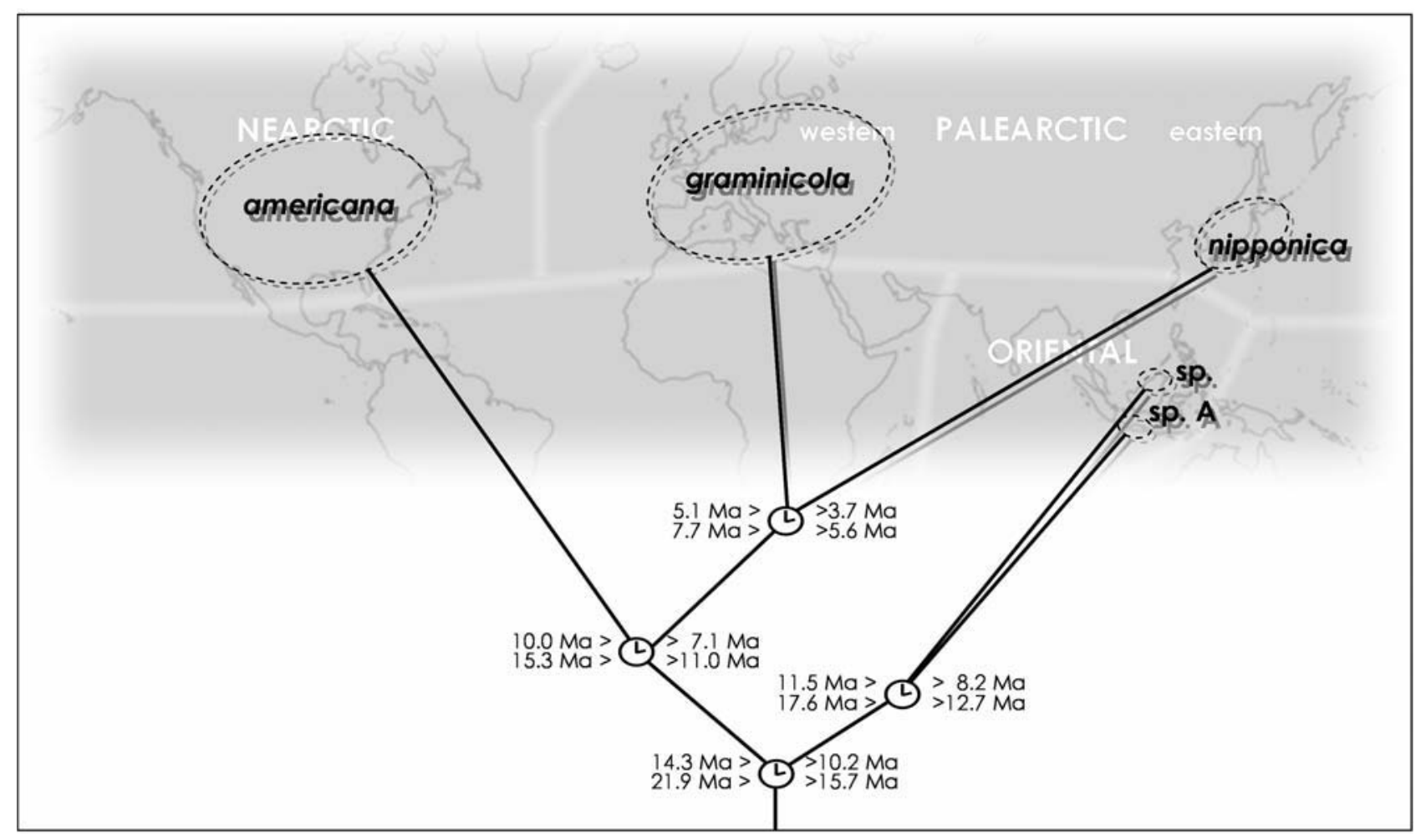

Fig. 2. Phylogenetic tree of Myrmecina species superimposed over a diagram of the species ranges. Biogeographical regions simplified from Dettner \& Peters (1999). Age estimates of key nodes in Ma (mega-annum): maximum and minimum age based on a nucleotide substitution of $2.3 \%$ per million years (above) and $1.5 \%$ per million years (below).

Lasius, Messor, Myrmica, Solenopsis, and Tetramorium ants (Savolainen and Vepsäläinen, 2003; Goropashnaya et al., 2004; Steiner et al., 2004; Heinze et al., 2005; Knaden et al., 2005; Ross \& Shoemaker, 2005; SchlickSteiner et al., 2005; Steiner et al., 2005a, b, 2006; Schlick-Steiner et al., 2006, in press). However, the phylogeny presented here was derived from a single gene and thus may not accurately reflect the species history. More independent loci are needed to build a stronger inference of the branching history of these Myrmecina species.

\section{How old is queen polymorphism in Myrmecina?}

Morphological differences between ant queens and workers are typically pronounced (Peeters, 1991; Heinze, 1998). Most ant species have gynomorphic (winged) queens (Buschinger \& Heinze, 1992). Given the evolutionary origin of Formicidae from winged vespoid hymenopterans (Hölldobler \& Wilson, 1990), intermorphic (wingless) queens probably constitute a derived trait in ants. But within Myrmecina, is the occurrence of intermorphic queens ancestral or the result of convergent evolution? In the light of the distribution of intermorphs in Asia, America, and Europe we consider multiple origin improbable. A more parsimonious assumption is that queen polymorphism constitutes an ancestral trait, probably acquired prior to the deepest branching event in the Myrmecina tree (Fig. 2). If true, this suggests that the apparent absence of gynomorph queens in $M$. sp. A (Ito, 1996) is an autapomorphic loss, although further sam- pling may well reveal $M$. sp. A colonies with gynomorphs.

Since the present DNA analysis includes all known Myrmecina species with intermorphs, our attempt to estimate the age of queen polymorphism in the genus appears justified. The deepest node in the tree (Fig. 2) dates queen polymorphism back to at least $10 \mathrm{Ma}$, the late Miocene (Palmer \& Geissman, 1999). This entails evolutionary stasis of queen polymorphism over a long period, which is, however, much shorter than the 100 million years inferred for behavioural and reproductive traits of the army ant syndrome (Brady, 2003). The selective advantage of ecological versatility may have facilitated the conservation of queen polymorphism during the radiation of the genus Myrmecina: Dispersal risk, climatic conditions, food availability, habitat patchiness, and habitat saturation are suggested to correlate with alternate queen morphs in ants (Ohkawara et al., 1993; Herbers, 1993; Keller, 1995; Pedersen \& Boomsma, 1999; Buschinger \& Schreiber, 2002; Murakami et al., 2002). Several authors have proposed habitat-dependent selection of this trait: A large queen morph (gynomorphic queens in Myrmecina) with usually long-distance dispersal and independent colony foundation may be beneficial in large, continuous habitats, whereas a small queen morph (intermorphic queens in Myrmecina) with short-distance dispersal and dependent colony foundation should be advantageous in small, isolated habitats (e.g., Heinze \& Buschinger, 1989; Heinze \& Tsuji, 1995; Stille, 1996; DeHeer et al., 1999; Rüppell \& Heinze, 1999). The underlying mechanism 
could be conceived as frequency-dependent selection in such a way that large, sparsely populated habitats favor large queens and small habitats with denser population favor small queens.

To our knowledge, only two papers have addressed formicid within-caste polyphenism in a phylogenetic context. In the genus Cardiocondyla male polymorphism was found to be ancestral (Heinze et al., 2005). In Tetramorium moravicum Kratochvil, 1941, the only queen-polymorphic member in a large genus, the situation differs markedly from Myrmecina and Cardiocondyla: a simple size dimorphism is geographically confined (Schlick-Steiner et al., 2005) and probably of Holocene (0.01 Ma) origin (B.C. Schlick-Steiner et al., unpubl.).

\section{Historical biogeography}

The small sample size and uncertainties of molecularclock dating (reviewed by Bromham \& Penny, 2003) only allows a tentative draft of the historical biogeography of Myrmecina. Compared to well-founded hypotheses concerning the impact of Pleistocene (1.8-0.01 Ma) climatic oscillations on speciation events and range shifts (reviewed by Hewitt, 2004), little is known about the dynamics that shaped terrestrial biodiversity during the Pliocene (5.3-1.8 Ma) and Miocene (23.8-5.3 Ma) (Sanmartín et al., 2001), the inferred time frame of diversification in our Myrmecina tree (Fig. 2). In the Miocene, the clade that presently occupies the oriental region diverged first, followed by the clade found in the nearctic region. Eventually, during the Pliocene, the western and the eastern palearctic clades diverged. The pattern of a nearctic-palearctic divergence and a subsequent divergence of the western and eastern palearctic lineages is in agreement with comprehensive biogeographical analyses of the holarctic fauna (reviewed by Sanmartín et al., 2001). The relatively recent divergence of the eastern and western palearctic lineages is paralleled by two pairs of morphologically similar ants, which were recently shown to constitute well separated species: the myrmicine Tetramorium tsushimae Emery, 1925 and T. cf. caespitum (Linnaeus, 1758) (Steiner et al., 2006) and the formicine Lasius nipponensis Forel, 1912 and L. fuliginosus (Latreille, 1798) (Espadaler et al., 2001).

ACKNOWLEDGEMENTS. We gratefully thank the Austrian Science Fund, FWF, for funding; Sabah Parks (Sabah, Malaysia) for permission to collect ants; F. Ito, S. Miyazaki, K. Ohkawara and A. Tartally for donating samples; A. Stradner for assistance with the molecular analysis; W. Ehrhardt for help in maintaining colonies in the laboratory; T. Miura for access to an article in press and two anonymous referees for constructive criticism.

\section{REFERENCES}

Agosti D. \& Johnson N.F. 2005: Antbase. World Wide Web electronic publication. <http://antbase.org/antbase.org>, accessed on 15 August 2005.

Alloway T.M., Buschinger A., Talbot M., Stuart R. \& Thomas C. 1982: Polygyny and polydomy in three North American species of the ant genus Leptothorax Mayr (Hymenoptera: Formicidae). Psyche 89: 249-274.
Bargum K., Boomsma J.J. \& Sundström L. 2004: A genetic component to size in queens of the ant, Formica truncorum. Behav. Ecol. Sociobiol. 57: 9-16.

Bolton B. 1995: A New General Catalogue of the Ants of the World. Harvard University Press, Cambridge, MA, 504 pp.

BRADY S.G. 2003: Evolution of the army ant syndrome: The origin and long-term evolutionary stasis of a complex of behavioral and reproductive adaptations. Proc. Natl. Acad. Sci. USA 100: 6576-6579.

Bromham L. \& Penny D. 2003: The modern molecular clock. Nature Rev. Genet. 4: 216-224.

BRower A.V.Z. 1994: Rapid morphological radiation and convergence among races of the butterfly Heliconius erato inferred from patterns of mitochondrial DNA evolution. Proc. Natl. Acad. Sci. USA 91: 6491-6495.

BRown W.L. 1967: Studies on North American ants. II. Myrmecina. Entomol. News 78: 233-240.

BUSCHINGER A. 2005: Experimental evidence for genetically mediated queen polymorphism in the ant species Myrmecina graminicola (Hymenoptera: Formicidae). Entomol. Gener. 27: 185-200.

Buschinger A. \& Alloway T.M. 1978: Caste polymorphism in Harpagoxenus canadensis M.R. Smith (Hym., Formicidae). Insectes Soc. 25: 339-350.

Buschinger A. \& Heinze J. 1992: Polymorphism of female reproductives in ants. In Billen J. (ed.): Biology and Evolution of Social Insects. Leuven University Press, Leuven, pp. $11-23$.

Buschinger A. \& Schreiber M. 2002: Queen polymorphism and queen-morph related facultative polygyny in the ant, Myrmecina graminicola (Hymenoptera, Formicidae). Insectes Soc. 49: 344-353.

Buschinger A., Schlick-Steiner B.C., Steiner F.M. \& EspaDALER X. 2003: On the geographic distribution of queen polymorphism in Myrmecina graminicola (Hymenoptera: Formicidae). Myrmecol. Nachr. 5: 37-41.

Creighton W.S. 1950: The ants of North America. Bull. Mus. Comp. Zool. 104: 1-585.

Czechowski W., Radchenko A. \& Czechowska W. 2002: The Ants (Hymenoptera, Formicidae) of Poland. Muzeum i Instytut Zoologii PAN, Warszawa, 200 pp.

DeHeer C.J., Goodisman M.A.D. \& Ross K.G. 1999: Queen dispersal strategies in the multiple-queen form of the fire ant Solenopsis invicta. Am. Nat. 153: 660-675.

Dettner K. \& Peters W. 1999: Lehrbuch der Entomologie. Gustav Fischer, Stuttgart, Jena, Lübeck, Ulm, 921 pp.

EMERY C. 1895: Beiträge zur Kenntniss der nordamerikanischen Ameisenfauna (Schluss). Zool. Jb. Abt. Syst. Ökol. Geogr. Tiere 8: 257-360.

Espadaler X., Akino T. \& Terayama M. 2001: Taxonomic status of the ant Lasius nipponensis Forel, 1912 (Hymenoptera, Formicidae). Nouv. Rev. Entomol. (N.S.) 18: 335-341.

Folmer O., Black M., Hoeh W., Lutz R. \& Vrijenhoek R. 1994: DNA primers for amplification of mitochondrial cytochrome c oxidase subunit I from diverse metazoan invertebrates. Mol. Mar. Biol. Biotechnol. 3: 294-299.

Francoeur A. 2000: Entomofaune du Québec: Liste des espèces de fourmis (Formicides, Hymenoptères). Document faunique 1: 1-10, retrieved from <http://entomofaune.qc.ca/publicat/ DF01-formicides.pdf $>$, on 14 August 2005.

Fraser V.S., Kaufmann B., Oldroyd B.P. \& Crozier R.H. 2000: Genetic influence on caste in the ant Camponotus consobrinus. Behav. Ecol. Sociobiol. 47: 188-194.

Goropashnaya A.V., Fedorov V.B. \& Pamilo P. 2004: Recent speciation in the Formica rufa group ants (Hymenoptera, For- 
micidae): inference from mitochondrial DNA phylogeny. Mol. Phylogen. Evol. 32: 198-206.

HeInZE J. 1998: Intercastes, intermorphs, and ergatoid queens: who is who in ant reproduction? Insectes Soc. 45: 113-124.

Heinze J. \& Buschinger A. 1989: Queen polymorphism in Leptothorax spec. A: Its genetic and ecological background (Hymenoptera: Formicidae). Insectes Soc. 36: 139-155.

Heinze J. \& TsujI K. 1995: Ant reproductive strategies. Res. Popul. Ecol. 37: 135-149.

Heinze J., Trindl A., Seifert B. \& Yamauchi K. 2005: Evolution of male morphology in the ant genus Cardiocondyla. Mol. Phylogen. Evol. 37: 278-288.

HERBERS J.M. 1993: Ecological determinants of queen number in ants. In Keller L. (ed.): Queen Number and Sociality in Insects. Oxford University Press, Oxford, pp. 262-293.

HewitT G.M. 2004: The structure of biodiversity - insights from molecular phylogeography. Frontiers Zool. 1: 4.

Hölldobler B. \& Wilson E.O. 1990: The Ants. The Belknap Press of Harvard University Press, Cambridge, MA, 732 pp.

Huelsenbeck J.P. \& Rannala B. 1997: Phylogenetic methods come of age: testing hypotheses in an evolutionary context. Science 276: 227-232.

Hughes W.O.H., Sumner S., Van Borm S. \& Boomsma J.J. 2003: Worker caste polymorphism has a genetic basis in Acromyrmex leaf-cutting ants. Proc. Natl. Acad. Sci. USA 100: 9394-9397.

Iто F. \& AoKi J.-I. 2003: Bionomics of the myrmecophilous oribatid mite Protoribates myrmecophilus (Acari: Oribatida) in the Oriental tropics. J. Nat. Hist. 37: 2383-2391.

Iто F. 1996: Colony characteristics of the Indonesian myrmicine ant Myrmecina sp. (Hymenoptera, Formicidae, Myrmicinae): polygynous reproduction by ergatoid queens. Ann. Entomol. Soc. Am. 89: 550-554.

Jовв G. 2005: Treefinder Manual. Version of June 2005. Retrieved from $<\mathrm{http}: / / \mathrm{www}$.treefinder.de/tf-june2005manual.pdf>, on 14 August 2005.

Jobi G., van Haeseler A. \& Strimmer K. 2004: TREEFINDER: a powerful graphical analysis environment for molecular phylogenetics. BMC Evol. Biol. 4: 18.

KeLLeR L. 1995: Social life: the paradox of multiple-queen colonies. Trends Ecol. Evol. 10: 355-360.

Knaden M., Tinaut A., Cerdá X., Wehner S. \& Wehner R. 2005: Phylogeny of three parapatric species of desert ants, Cataglyphis bicolor, C. viatica and C. savignyi: a comparison of mitochondrial DNA, nuclear DNA, and morphological data. Zoology 108: 169-177.

KrIeger M.J.B. \& Ross K.G. 2002: Identification of a major gene regulating complex social behavior. Science 295: 328-332.

LinksVAYer T.A: 2005: Social Evolution in Ants: Direct and Indirect Genetic Effects. Unpublished $\mathrm{PhD}$ thesis. Indiana University, Bloomington, IN.

MiURA T. 2005: Developmental regulation of caste-specific characters in social-insect polyphenism. Evol. Devel. 7: $122-129$.

Miyazaki S., Murakami T. Azuma N., Higashi S. \& Miura T. 2005: Morphological differences among three female castes: worker, queen and intermorphic queen in the ant Myrmecina nipponica (Formicidae: Myrmicinae). Sociobiology 46: 363-374.

Murakami T., OhKwara K. \& Higashi S. 2002: Morphology and developmental plasticity of reproductive females in Myrmecina nipponica (Hymenoptera: Formicidae). Ann. Entomol. Soc. Am. 95: 577-582.

Murakami T., Wang L. \& Higashi S. 2000: Mating frequency, genetic structure, and sex ratio in the intermorphic female producing ant species Myrmecina nipponica. Ecol. Entomol. 25: 341-347.

Ogata K. \& Terayama M. 2003: Myrmecina nipponica. Retrieved from <http://ant.edb.miyakyo-u.ac.jp/E/Taxo/ F41902.html $>$ on 17 August 2005.

OhKawara K., Ito F. \& Higashi S. 1993: Production and reproductive function of intercastes in Myrmecina graminicola nipponica colonies (Hymenoptera: Formicidae). Insectes Soc. 40: $1-10$.

Onoyama K. 1997: Taxonomic notes on the ant Myrmecina nipponica Wheeler stat. nov. (Hymenoptera: Formicidae). Res. Bull. Obihiro Univ. Nat. Sci. 20: 151-153.

Palmer A.R. \& Geissman J. 1999: 1999 Geologic Time Scale. Geological Society of America, Product code CTS004.

Pedersen J.S. \& Boomsma J.J. 1999: Effect of habitat saturation on the number and turnover of queens in the polygynous ant, Myrmica sulcinodis. J. Evol. Biol. 12: 903-917.

Peeters C.P. 1991: Ergatoid queens and intercastes in ants: two distinct adult forms which look morphologically intermediate between workers and winged queens. Insectes Soc. 38: 1-15.

Posada D. \& Crandall K.A. 1998: Modeltest: testing the model of DNA substitutions. Bioinformatics 14: 817-818.

Quek S.-P., Davies S.J., Itino T. \& Pierce N.E. 2004: Codiversification in an ant-plant mutualism: stem texture and the evolution of host use in Crematogaster (Formicidae: Myrmicinae) inhabitants of Macaranga (Euphorbiaceae). Evolution 58: 554-570.

Ronquist F. \& Huelsenbeck J.P. 2003: MrBayes 3: Bayesian phylogenetic inference under mixed models. Bioinformatics 19: $1572-1574$.

Ross K.G. \& Shoemaker D.D. 2005: Species delimitation in native South American fire ants. Mol. Ecol. 14: 3419-3438.

RüPPELL O. \& HeINZE J. 1999: Alternative reproductive tactics in females: the case of size polymorphism in winged ant queens. Insectes Soc. 46: 6-17.

Rüppell O., Heinze J. \& Hölldobler B. 2001: Complex determination of queen body size in the queen size dimorphic ant Leptothorax rugatulus (Formicidae: Hymenoptera). Heredity 87: $33-40$

Sanmartín I., Enghoff H. \& Ronquist F. 2001: Patterns of animal dispersal, vicariance and diversification in the Holarctic. Biol. J. Linn. Soc. 73: 345-390.

SAVOlAINEN R. \& VePSÄLÄINEN K. 2003: Sympatric speciation through intraspecific social parasitism. Proc. Natl. Acad. Sci. USA 100: 7169-7174.

Schlick-Steiner B.C., Steiner F.M., Sanetra M., Heller G., Stauffer C., Christian E. \& Seifert B. 2005: Queen size dimorphism in the ant Tetramorium moravicum (Hymenoptera, Formicidae): Morphometric, molecular genetic and experimental evidence. Insectes Soc. 52: 186-193.

Schlick-Steiner B.C., Steiner F.M., Konrad H., Markó B., Csõsz S., Heller G., Ferencz B., Sipos B., Christian E. \& STAUfFER C. 2006: More than one species of Messor harvester ants (Hymenoptera: Formicidae) in Central Europe. Eur. J. Entomol. 103: 469-476.

Schlick-Steiner B.C., Steiner F.M., Moder K., Seifert B., Sanetra M., Dyreson E., Stauffer C. \& Christian E. in press: A multidisciplinary approach reveals cryptic diversity in western Palaearctic Tetramorium ants (Hymenoptera: Formicidae). Mol. Phylogenet. Evol.

Simon C., Frati F., Beckenbach A., Crespi B., Liu H. \& Flook P. 1994: Evolution, weighting, and phylogenetic utility of mitochondrial gene sequences and a compilation of conserved polymerase chain reaction primers. Ann. Entomol. Soc. Am. 87: $651-701$. 
Steiner F.M., Schlick-Steiner B.C., Schödl S., Espadaler X., Seifert B., Christian E. \& Stauffer C. 2004: Phylogeny and bionomics of Lasius austriacus (Hymenoptera, Formicidae). Insectes Soc. 51: 24-29.

Steiner F.M., Schlick-Steiner B.C., Konrad H., Moder K., Christian E., Seifert B., Crozier R.H., Stauffer C. \& BuschINGER A. 2005a: No sympatric speciation here: Multiple data sources show that the ant Myrmica microrubra is not a separate species but an alternate reproductive morph of Myrmica rubra. J. Evol. Biol., doi: 10.1111/j.1420-9101.2005.01053.x.

Steiner F.M., Schlick-Steiner B.C., Sanetra M., Ljubomirov T., Antonova V., Christian E. \& Stauffer C. 2005b: Towards DNA-aided biogeography: an example from Tetramorium ants (Hymenoptera, Formicidae). Ann. Zool. Fenn. 42: 23-35.

Steiner F.M., Schlick-Steiner B.C., Trager J.C., Moder K., Sanetra M., Christian E. \& Stauffer C. 2006: Tetramorium tsushimae, a new invasive ant in North America. Biol. Invas. 8: $117-123$.

STILLE M. 1996: Queen/worker thorax volume ratios and nestfounding strategies in ants. Oecologia 105: 87-93.
Swofford D.L. 1998: PAUP*. Phylogenetic Analysis Using Parsimony (*And Other Methods). Version 4.0b3. Sinauer, Sunderland, MA.

TAVARÉ S. 1986: Some probabilistic and statistical problems on the analysis of DNA sequences. Lect. Math. Life Sci. 17: 57-86.

Thompson J.D., Gibson T.J., Plewniak F., Jeanmougin F. \& HigGINS D.G. 1997: The Clustal-X windows interface: Flexible strategies for multiple sequence alignment aided by quality analysis tools. Nucl. Acids Res. 25: 4876-4882.

Volny V.P. \& GoRdon D.M. 2002: Genetic basis for queenworker dimorphism in a social insect. Proc. Natl. Acad. Sci. USA 99: 6108-6111.

WARD P.S. 2005: A synoptic review of the ants of California (Hymenoptera: Formicidae). Zootaxa 936: 1-68.

WINTER U. \& BUSCHINGER A. 1986: Genetically mediated queen polymorphism and caste determination in the slave-making ant, Harpagoxenus sublaevis (Hymenoptera: Formicidae). Entomol. Gener. 11: 125-137.

YANG Z. 1993: Maximum-likelihood estimation of phylogeny from DNA sequences when substitution rates differ over sites. Mol. Biol. Evol. 10: 1396-1401.

Received January 31, 2006; revised and accepted March 3, 2006 